\title{
Correlation and Path Analysis for Different Characteristics in Germplasm of Finger Millet (Eleusine coracana (L.) Gaertn.)
}

\author{
Sneha R. Sapkal, V.V. Bhavsar*, K.K. Barhate and Sarika N. Kohakade \\ Department of Agricultural Botany, College of Agriculture (Mahatma Phule Krishi \\ Vidyapeeth), Dhule (MS), India \\ *Corresponding author
}

\section{A B S T R A C T}

\begin{tabular}{|l|}
\hline Ke y w o r d s \\
Correlation \\
coefficient, Path \\
analysis, \\
$\begin{array}{l}\text { Germplasms, Finger } \\
\text { millet (Eleusine } \\
\text { coracana (L.) } \\
\text { Gaertn.) }\end{array}$ \\
\hline Article Info \\
\hline $\begin{array}{l}\text { Accepted: } \\
\text { 10 December } 2018 \\
\text { Available Online: } \\
\text { 10 January } 2019\end{array}$ \\
\hline \hline
\end{tabular}

Keywords

Correlation

coefficient, Path

analysis,

millet (Eleusine

coracana $(L$.

Article Info

Accepted:

0 December 2018

Available Online:

\section{Introduction}

Millet is a collective term referring to a number of small seeded annuals grasses that are cultivated as grain crops, primarily on marginal lands in dry areas in temperate, subtropical and tropical regions. Finger millet, (Eleusine coracana), is also known as African millet, ragi, nachani, nagali. Finger millet (Eleusine coracana (L.) Gaertn.), is one among highly utilized belong to family Poaceae and it ranks $4^{\text {th }}$ in the importance of world. Finger millet is originated from Ethiopia. It is allopolyploid with chromosome number $2 n=4 x=36$ and evolved from a cross between two diploid species Eleusine indica (AA) and Eleusine floccifolia or Eleusine tristachya (BB) as genome contributors (Hiremat and Salimath, 1992). Finger millet is mostly self pollinating with some amount of cross pollination (1\%) mediated by wind (Jansen and Ong, 1996, Purseglove, 1972). It is important staple food in parts of eastern and Central Africa and India. Finger millet is very 
adaptable to a wide range of environmental and climatic conditions, thrives at higher elevations than most other tropical cereals and tolerates salinity better than moist cereals. It is important cereal in Karnataka. It is intensively grown in Karnataka, Tamil Nadu, Andhra Pradesh, Orissa, Bihar, Gujarat, Maharashtra and in the hilly regions of Uttar Pradesh, Himachal Pradesh with a total area of 2.5 million hectares and 2.2 million tones of production.

Correlation studies provide knowledge of association among different characters and grain yield. The study of association among various traits is useful for breeders in selecting genotypes possessing groups of desired traits. The correlation coefficients become insufficient for using yield components as selection criteria to improve grain yields. It is reasonable to know whether any yield components has a direct or indirect effect on grain yield, so that selection studies can be carried out successfully.

Correlated response: Two characters say $\mathrm{x}$ and $\mathrm{y}$, are correlated. A change in the mean of $\mathrm{x}$ through selection will cause an associated change in the mean of y also. This change in $y$ brought about through indirect selection on an associated character $\mathrm{x}$ is known as correlated response (Singh and Chaudhary, 1977).

The path coefficient analysis provides a more realistic picture of the relationship as it considers direct as well as indirect effects of the variables by partitioning the correlation coefficients.

Correlation and path analysis estimates between yield and other characters are useful in selecting desired plant type in designing an effective breeding programme. When change in one variable causes the change on other variable, the variables are said to be correlated. Keeping the above facts a view, the present investigation entitled, "Correlation and Path Analysis for Different Characteristics in Germplasm of Finger Millet (Eleusine coracana (L.) Gaertn.)" was proposed to gather information on the following objectives:

To better insight into the cause and effect relationship between pairs of characters, study of correlation in conjunction with path analysis is essential.

\section{Materials and Methods}

The experimental materials consisting forty germplasm of finger millet collected from Nashik, Dhule, Ahmednagar, Satara Pune, Jalgaon and Nandurbar districts of Maharashtra. The experiment was laid out in RBD with three replications at Department of Botany, College of Agriculture, Dhule (M.S.) during Kharif 2017. By adopting a spacing of $22.5 \mathrm{~cm}$ between rows and $10 \mathrm{~cm}$ between plants respectively, at recommended package of practices were followed to raise good and healthy crop stand. Data were collected on eleven yield and yield contributing characters viz., days to $50 \%$ flowering, days to maturity, plant height $(\mathrm{cm})$, number of tillers per plant, number of productive tillers per plant, main eahead length $(\mathrm{cm})$, number of fingers per earhead, $100 \mathrm{ml}$ volume weight, grain yield per plant (g) and qualitative characters viz., grain iron content $(\mathrm{mg} / 100 \mathrm{~g})$, grain calcium content $(\mathrm{mg} / 100 \mathrm{~g})$.

The mean of five plants was subjected to statistical analysis. The data for different characters were statistically analyzed for significance by using analysis of variance technique described by Panse and Sukhatme (1985).The adapted design was Randomized Block Design (RBD) with three replications. The significance of mean sum of square for each character was tested against the corresponding error degrees of freedom using 
"F" Test (Fisher and Yates, 1967). Correlation between eleven characters was estimated according to the method given by Singh and Chaudhary (1977). Direct and indirect effects were estimated as described by Dewey and Lu (1959). Statistical analysis was done by using WINDOSTAT program.

\section{Results and Discussion}

Analysis of variance revealed significant differences among genotypes for all the characters (Table 1).

Analysis of variance for eleven characters indicated that the genotypes used in the present studies were significantly different. The correlation coefficients at both genotypic and phenotypic levels estimated between grain yields per plant with all other characters are presented in Table 2 and 3 respectively. In the present investigation, the genotypic correlation coefficients were higher than the phenotypic correlation coefficients as observed by Johnson et al., (1955). This might have occurred due to genes governing two traits were similar and the environmental conditions pertaining to the expression of these traits might have small and similar effects.

Grain yield exhibited highly significant positive correlation with all other characters except plant height, $100 \mathrm{ml}$ volume weight, grain calcium content suggesting dependency of yield on these characters (Table 2 and 3). The highest association of yield was with days to 50 per cent flowering (0.847) followed by days to maturity (0.831), number of productive tillers per plant (0.831), number of tillers per plant (0.796), main earhead length (0.677), number of fingers per earhead (0.468). While grain yield per plant showed non-significant positive genotypic correlation with grain iron content (0.106). But, it showed non-significant negative genotypic correlation with $100 \mathrm{ml}$ volume weight ($0.172)$, grain calcium content $(-0.130)$ and plant height (-0.041). These results are in accordance with the findings of Rao (1992), Ramakrishna et al., (1996), Gowda (1996), Ramakrishna et al., (1996), Mahto et al., (2000), Chaudhari and Bedis et al., (2006) and Gowda et al., (2008), Ganapathya et al., (2011).

Table.1 Analysis of variance for different characters in finger millet

\begin{tabular}{|c|l|c|c|c|}
\hline \multirow{2}{*}{$\begin{array}{c}\text { Sr. } \\
\text { No }\end{array}$} & \multicolumn{1}{|c|}{ Characters } & \multicolumn{3}{|c|}{ Mean sum of square } \\
\cline { 2 - 4 } & \multicolumn{1}{|c|}{ Replication } & Genotype & Error \\
\hline $\mathbf{1}$ & Days to 50\% flowering & 33.908 & $279.59^{* *}$ & 16.429 \\
\hline $\mathbf{2}$ & Days to maturity & 33.033 & $393.21^{* *}$ & 35.272 \\
\hline $\mathbf{3}$ & Plant height (cm) & 41.308 & $415.080^{* *}$ & 45.445 \\
\hline $\mathbf{4}$ & No. of tillers / plant & 0.582 & $7.679^{* *}$ & 0.308 \\
\hline $\mathbf{5}$ & No. of productive tillers / plant & 0.410 & $6.308^{* *}$ & 0.210 \\
\hline $\mathbf{6}$ & Main earhead length $(\mathrm{cm})$ & 0.290 & $11.546^{* *}$ & 0.272 \\
\hline $\mathbf{7}$ & No. of fingers / earhead & 0.614 & $6.986^{* *}$ & 0.374 \\
\hline $\mathbf{8}$ & 100 ml volume weight $(\mathrm{gm})$ & 16.808 & $662.402^{* *}$ & 14.859 \\
\hline $\mathbf{9}$ & Grain yield / plant $(\mathrm{gm})$ & 8.258 & $210.99 * *$ & 4.053 \\
\hline $\mathbf{1 0}$ & Grain iron content $(\mathrm{mg} / 100 \mathrm{gm})$ & 0.069 & $19.561^{* *}$ & 0.069 \\
\hline $\mathbf{1 1}$ & Grain calcium content $(\mathrm{mg} / 100 \mathrm{gm})$ & 1210.40 & $11756.44^{* *}$ & 554.75 \\
\hline
\end{tabular}

*, ** Indicates significance at $5 \%$ and $1 \%$ level, respectively 
Table. 2 Genotypic correlation coefficient for eleven characters in finger millet

\begin{tabular}{|c|c|c|c|c|c|c|c|c|c|c|c|c|}
\hline & Characters & 1 & 2 & 3 & 4 & 5 & 6 & 7 & 8 & 9 & 10 & 11 \\
\hline 1. & Days to 50 per cent flowering & 1.000 & $0.992 * *$ & 0.055 & $0.732 * *$ & $0.774 * *$ & $0.592 * *$ & $0.442 * *$ & -0.124 & -0.055 & $-0.201 *$ & $0.847 * *$ \\
\hline 2. & Days to maturity & & 1.000 & 0.084 & $0.749 * *$ & $0.795 * *$ & $0.577 * *$ & $0.386^{* *}$ & $-0.202 *$ & $-0.183^{*}$ & -0.164 & $0.831^{* *}$ \\
\hline 3. & Plant height & & & 1.000 & 0.112 & 0.112 & 0.127 & $-0.297 * *$ & $-0.240 * *$ & $0.199^{*}$ & $0.283^{* *}$ & -0.041 \\
\hline 4. & No. of tillers /plant & & & & 1.000 & $0.998 * *$ & $0.630 * *$ & $0.295 * *$ & $-0.252 * *$ & $0.224 * *$ & -0.027 & $0.796^{* *}$ \\
\hline 5. & No. of productive tillers/plant & & & & & 1.000 & $0.669^{* *}$ & $0.310 * *$ & $-0.222 *$ & $0.213 * *$ & -0.033 & $0.831^{* *}$ \\
\hline 6. & Main earhead length & & & & & & 1.000 & 0.030 & -0.164 & 0.169 & -0.114 & $0.677 * *$ \\
\hline 7. & No. of fingers /earhead & & & & & & & 1.000 & -0.147 & -0.061 & -0.150 & $0.468 * *$ \\
\hline 8. & $100 \mathrm{ml}$ volume weight & & & & & & & & 1.000 & 0.111 & 0.062 & -0.172 \\
\hline 9. & Grain iron content & & & & & & & & & 1.000 & $0.425^{* *}$ & 0.106 \\
\hline 10. & Grain calcium content & & & & & & & & & & 1.000 & -0.130 \\
\hline 11. & Grain yield per plant & & & & & & & & & & & 1.000 \\
\hline
\end{tabular}

*,** Indicates significance at $5 \%$ and $1 \%$ level, respectively

Table.3 Phenotypic correlation for eleven characters in finger millet

\begin{tabular}{|c|c|c|c|c|c|c|c|c|c|c|c|c|}
\hline & Characters & 1 & 2 & 3 & 4 & 5 & 6 & 7 & 8 & 9 & 10 & 11 \\
\hline 1 & $\begin{array}{l}\text { Days to } 50 \text { per cent } \\
\text { flowering }\end{array}$ & 1.000 & $0.803 * *$ & 0.027 & $0.625 * *$ & $0.675 * *$ & $0.513 * *$ & $0.384 * *$ & -0.130 & -0.058 & -166 & $0.776 * *$ \\
\hline 2 & Days to maturity & & 1.000 & 0.082 & $0.593 * *$ & $0.629 * *$ & $0.531 * *$ & $0.276 * *$ & $-0.194 *$ & -0.154 & -0.155 & $0.710 * *$ \\
\hline 3 & Plant height & & & 1.000 & 0.085 & 0.088 & 0.116 & $-0.226^{*}$ & $-0.217^{*}$ & $0.186^{*}$ & $0.221 *$ & -0.016 \\
\hline 4 & No. of tillers /plant & & & & 1.000 & $0.917 * *$ & $0.586 * *$ & $0.261 * *$ & $-0.236 * *$ & $0.208^{*}$ & -0.040 & $0.704 * *$ \\
\hline 5 & $\begin{array}{l}\text { No. of productive } \\
\text { tillers/plant }\end{array}$ & & & & & 1.000 & $0.593 * *$ & $0.76^{* *}$ & $-0.200 *$ & $0.198 *$ & -0.029 & $0.759 * *$ \\
\hline 6 & Main earhead length & & & & & & 1.000 & 0.020 & -0.165 & 0.168 & -0.114 & $0.629 * *$ \\
\hline 7 & No. of fingers /earhead & & & & & & & 1.000 & -0.129 & -0.052 & -0.125 & $0.410^{* *}$ \\
\hline 8 & $100 \mathrm{ml}$ volume weight & & & & & & & & 1.000 & 0.101 & 0.074 & -0.165 \\
\hline 9 & Grain iron content & & & & & & & & & 1.000 & $0.397 * *$ & 0.099 \\
\hline 10 & Grain calcium content & & & & & & & & & & 1.000 & -0.108 \\
\hline 11 & Grain yield per plant & & & & & & & & & & & 1.000 \\
\hline
\end{tabular}


Table.4 Genotypic path co-efficient for eleven characters in finger millet

\begin{tabular}{|r|l|l|l|l|l|l|l|l|l|l|l|l|}
\hline & \multicolumn{1}{|c}{ Characters } & $\mathbf{1}$ & $\mathbf{2}$ & $\mathbf{3}$ & $\mathbf{4}$ & $\mathbf{5}$ & $\mathbf{6}$ & $\mathbf{7}$ & $\mathbf{8}$ & $\mathbf{9}$ & $\mathbf{1 0}$ & $\mathbf{1 1}$ \\
\hline $\mathbf{1}$ & Days to 50 per cent flowering & 0.675 & 0.670 & 0.037 & 0.494 & 0.523 & 0.400 & 0.298 & -0.084 & -0.037 & -0.136 & $0.847^{* *}$ \\
\hline $\mathbf{2}$ & Days to maturity & -0.200 & -0.201 & -0.017 & -0.151 & -0.160 & -0.116 & -0.077 & 0.040 & 0.037 & 0.033 & $0.831^{* *}$ \\
\hline $\mathbf{3}$ & Plant height & -0.005 & -0.008 & -0.102 & -0.011 & -0.011 & -0.013 & 0.030 & 0.024 & -0.020 & -0.029 & -0.041 \\
\hline $\mathbf{4}$ & No. of tillers / plant & 0.479 & 0.491 & 0.073 & 0.655 & 0.658 & 0.413 & 0.193 & -0.165 & 0.147 & -0.018 & $0.796^{* *} *$ \\
\hline $\mathbf{5}$ & No. of productive tillers / plant & -0.310 & -0.318 & -0.045 & -0.4024 & -0.400 & -0.268 & -0.124 & 0.089 & -0.085 & 0.013 & $0.831^{* *}$ \\
\hline $\mathbf{6}$ & Main earhead length & 0.153 & 0.149 & 0.033 & 0.163 & 0.173 & 0.258 & 0.007 & -0.042 & 0.043 & -0.029 & $0.677^{* *}$ \\
\hline $\mathbf{7}$ & No. of fingers / earhead & 0.064 & 0.056 & -0.043 & 0.043 & 0.045 & 0.004 & 0.146 & -0.021 & -0.009 & -0.022 & $0.468^{* *}$ \\
\hline $\mathbf{8}$ & 100 ml volume weight & 0.002 & 0.003 & 0.004 & 0.004 & 0.003 & 0.002 & 0.002 & -0.017 & -0.002 & -0.001 & -0.172 \\
\hline $\mathbf{9}$ & Grain iron content & -0.0005 & -0.001 & 0.001 & 0.002 & 0.002 & 0.001 & -0.0006 & 0.001 & 0.009 & 0.003 & 0.106 \\
\hline $\mathbf{1 0}$ & Grain calcium content & -0.011 & -0.009 & 0.015 & -0.001 & -0.001 & -0.006 & -0.008 & 0.003 & 0.023 & 0.055 & -0.130 \\
\hline
\end{tabular}

Residual effect $=(0.4022) \quad$ Bold values indicated direct effect

$*, * *$ Indicates significance at $5 \%$ and $1 \%$ level, respectively

Table.5 Phenotypic path co-efficient for eleven characters in finger millet

\begin{tabular}{|r|l|l|l|l|l|l|l|l|l|l|l|l|}
\hline & \multicolumn{1}{|c|}{ Characters } & $\mathbf{1}$ & $\mathbf{2}$ & $\mathbf{3}$ & $\mathbf{4}$ & $\mathbf{5}$ & $\mathbf{6}$ & $\mathbf{7}$ & $\mathbf{8}$ & $\mathbf{9}$ & $\mathbf{1 0}$ & $\mathbf{1 1}$ \\
\hline $\mathbf{1}$ & $\begin{array}{l}\text { Days to 50 per cent } \\
\text { flowering }\end{array}$ & $\mathbf{0 . 2 9 7}$ & 0.239 & 0.008 & 0.186 & 0.201 & 0.153 & 0.114 & -0.038 & -0.017 & -0.049 & $0.776^{* *}$ \\
\hline $\mathbf{2}$ & Days to maturity & 0.119 & $\mathbf{0 . 1 4 8}$ & 0.012 & 0.088 & 0.093 & 0.078 & 0.040 & -0.028 & -0.023 & -0.023 & $0.710^{* *}$ \\
\hline $\mathbf{3}$ & Plant height & -0.001 & -0.005 & $\mathbf{- 0 . 0 6 6}$ & -0.005 & -0.005 & -0.007 & 0.015 & 0.014 & -0.012 & -0.014 & -0.016 \\
\hline $\mathbf{4}$ & No. of tillers / plant & -0.036 & -0.034 & -0.004 & $\mathbf{- 0 . 0 5 7}$ & -0.052 & -0.033 & -0.015 & 0.013 & -0.012 & 0.002 & $0.704 * *$ \\
\hline $\mathbf{5}$ & $\begin{array}{l}\text { No. of productive tillers / } \\
\text { plant }\end{array}$ & 0.221 & 0.206 & 0.029 & 0.300 & $\mathbf{0 . 3 2 7}$ & 0.194 & 0.090 & -0.065 & 0.064 & -0.009 & $0.759^{* *}$ \\
\hline $\mathbf{6}$ & Main earhead length & 0.117 & 0.121 & 0.026 & 0.134 & 0.136 & $\mathbf{0 . 2 2 9}$ & 0.004 & -0.037 & 0.038 & -0.026 & $0.629 * *$ \\
\hline $\mathbf{7}$ & No. of fingers / earhead & 0.062 & 0.045 & -0.037 & 0.042 & 0.045 & 0.003 & $\mathbf{0 . 1 6 3}$ & -0.021 & -0.008 & -0.020 & $0.410^{* *}$ \\
\hline $\mathbf{8}$ & 100 ml volume weight & 0.001 & 0.001 & 0.001 & 0.002 & 0.001 & 0.001 & 0.001 & $\mathbf{- 0 . 0 0 8}$ & -0.0009 & 0.0006 & -0.165 \\
\hline $\mathbf{9}$ & Grain iron content & -0.003 & -0.010 & 0.012 & 0.014 & 0.013 & 0.011 & -0.003 & 0.006 & $\mathbf{0 . 0 6 7}$ & 0.026 & 0.099 \\
\hline $\mathbf{1 0}$ & Grain calcium content & -0.001 & -0.001 & 0.001 & -0.003 & -0.002 & -0.0008 & -0.0009 & 0.0005 & 0.002 & $\mathbf{0 . 0 0 6}$ & -0.0007 \\
\hline
\end{tabular}

Residual effect $=(0.4854)$ Bold values indicated direct effect

$*, * *$ Indicates significance at $5 \%$ and $1 \%$ level, respectively 
The path coefficients at both genotypic and phenotypic levels estimated between grain yield per plant and yield contributing characters and qualitative characters were carried out by using correlation coefficient.

The results obtained are presented in Table 4 and 5, respectively. The characters which emerged as the major component of grain yield per plant in path coefficient analysis (Table 4 and 5) was exerted by days to $50 \%$ flowering followed by number of tillers per plant, main earhead length and number of fingers per earhead which had highest direct effects on grain yield per plant at genotypic level. At phenotypic level number of productive tillers per plant recorded maximum direct effect on grain yield per plant. This is in accordance with the findings of Anuradha et al., (2013), Kumar (2014), Jyothsna et al., (2016).

In general, correlation and path analysis carried concluded that the number of tillers per plant, number of productive tillers per plant, main earhead length, number of fingers per ear head influenced the grain yield more than any of the other characters. Hence, it would be worthwhile to lay more emphasis on these characters in selection programme to improve the grain yield in finger millet.

\section{References}

Anantharaju, P. and Meenakshiganesan, N. 2005. Studies on correlation and path coefficient analysis of yield and yield contributing characters in finger millet [Eleusine coracana (L.) Gaertn.]. Hisar, Crop. Res., 30(2): 227-230.

Anuradha, N., Udaya Bhanu, K., Patro, T. S. S. K. and Sharma N. D. R. K. 2013. Character association and path analysis in finger millet [Eleusine coracana (L.) Gaertn.]. accession belongs to late maturity group. Int. J.
Food, Agric. and Veterinary Sci., 3(3): 113-115.

Appadurai, R., Thangam, M. S., Ravindran, T. S. and Natarajan, V. S. 1977. Genotypic association, heritability and path analysis in ragi [Eleusine coracana (L.) Gaertn.]. Madras Agric. J., 64: 15-21.

Bandyopadhyay, B. B. 2009. Yield Variation and Associated Changes in Relationship of Component Characters of a Cold Sensitive Finger Millet Genotype in Subsequent Generation. Indian J. Agric. Res., 43: 32-36.

Bedis, M. R., Patil, H. S., Jangle, G. D. and Patil, V. S. 2006. Correlation and Path analysis in finger millet [Eleusine coracana (L.) Gaertn.]. Crop. Res., 31: 264-266.

Bendale, V. W., Bhave, S. G. and Pethe, U. B. 2002. Genetic variability, correlation and path analysis in finger millet [Eleusine coracana (L.) Gaertn.]. J. Soils and Crop., 12: 187-191.

Bezaweletaw, K., Sripichitt, P., Wongyai, W. and Hogtrakul, V., 2006. Genetic variation, heritability and path analysis in Ethiopian finger millet [Eleusine coracana (L.) Gaertn.] landraces. Kasetsart J. Nat. Sci., 40(2): 322-334.

Dewey, D. R. and K. H. Lu. 1959. A correlation and path analysis of components of crested wheat grass seed production. Agron. J., 51: 513518.

Dhamdhere, D. H., Pandey, P. K., Shrotria, P. K. and Ojha, O. P. 2013. Character association and path analysis in finger millet [Eleusine coracana (L.) Gaertn.]. Pantnagar J. Res., 11(2): 199-203.

Eric, M. O., Pangirayi, T., Paul, S., Mwangi, G. and Rathore, A. 2016. Correlations, Path Coefficient Analysis and Heritability for Quantitative Traits in Finger Millet 
Landraces. Philippine J. Sci., 145(2): 197-208.

Fisher, R.A. and Yates. 1967. Statistical Tables for Biological Agricultural and Medical Research Oliver and Boyd, Edington

Ganapathy and Kumuda, 2011, Correlation and path studies in finger millet (Eleusine coracana (L.) Gaertn.). Madras Agric. J., 54: 113117

Gowda, J., Shet, R., Suvarna, M. and Somu, G. 2008. Genetic variability and correlation studies in interspecific crosses of finger millet [Eleusine coracana (L.) Gaertn.]. Crop. Res., 36: $239-243$.

Hiremat, S.C. and Salimat S. S. 1992. The "A" genome donor of Eleusine coracana (L.) Gaertn. (Gramineae). Theoret. Appl. Genet. 84(5-6): 747754.

Jadhav, R. Ratna Babu, D., Lal Ahamed, M. and Srinivasa Rao, V. 2015. Character association and path coefficient analysis for grain yield and yield components in finger millet [Eleusine coracana (L.) Gaertn.]. Electronic J. Plant Breeding, 6(2): 535-539.

Jansen, P. M. C. and Ong, H. C. 1996. Eleusine coracana (L.) Gaertner ev. group Finge Millet. Plant Resources of South-East Asia No 10. Cereals, Backhuys Publishers, Leiden, Netherlands. Pp.90-95.

John, K. 2006. Variability and Correlation Studies in Quantitative traits of Finger Millet [Eleusine coracana Gaertn]. Agril. Sci. Digest., 26: 166-169.

Jyothsna, S., Patro, T. S. S. K., Ashok, S., Y. Sandhya Rani and Neeraja, B. 2016. Studies on Genetic Parameters, Character Association and Path Analysis of Yield and its Components in Finger Millet [Eluesine Coracana (L.) Gaertn.]. Int. J. Theoretical \& App. Sci., 8(1): 25-30.
Kadam, D. D., Kulkarni, S. R and Jadhav, B. S. 2009. Genetic variability, correlation and path analysis in finger millet (Eleusine coracana Gaertn). J. Mah. Agric. Uni. 34:131-134.

Kebere Bezaweletaw, Sripichitt, P., Wongyai, W. and Hongtrakul, V. 2006. Genetic variation, heritability and pathanalysis in Ethiopian finger millet [Eleusine coracana (L.) Gaertn] landraces. Kasetsart J. Nat. Sci., 40: 322-334.

Kumar, D., Tyagi, V. and Ramesh, B. 2014. Path Coefficient Analysis for Yield and its Contributing Traits in Finger Millet. Int. J. Adv. Res., 2(8): 235-240.

Mahto, R. N., Mahto, J. and Ganguli, D. K. 2000. Correlation and path coefficient analysis in ragi [Eleusine coracana (L.) Gaertn.] under rainfed condition. Birsa Agril. Uni. J. Res., 12: 81-83.

Mahudeswaran, K. and Murugesan, M. 1973. Correlation and path analysis in ragi. Madras Agric. J., 60(9): 1287-1291.

Nandini, B., Ravishankar, C. R., Mahesha, B. and Shailaja Hittalmani Murthy, K. N. K. 2010. Study of correlation and path analysis in $F_{2}$ population of finger millet. Int. J. Plant Sci., 5(2): 602-605.

Negi, S., Kumar, V. and Bhatt, A. 2017. Genetic Diversity among Finger Millet [Eleusine coracana (L.) Gaertn.] Genotypes for Yield and Its Contributing Traits. Int. J. Curr. Microbiol. App. Sci., 6(8): 3332-3337.

Panse, V. G. and P. V. Sukhatme. 1985 Statistical methods for agricultural workers. ICAR, New Delhi. $4^{\text {th }}$ Edition, pp. 97-156.

Purseglove J. W. 1972. Tropical crops: Monocotyledons. Molecular Nutrition and Food Research. 19(5-6): 395-524

Prabhakar and Prasad, M. N. 1983. Correlation and path analysis in segregating population of finger millet [Eleusine coracana (L.) Gaertn.]. 
Madras Agric. J., 70: 366-371.

Reddy, K. R., Reddy, C. R., Kumar, C. V. S., Sekhar, M. R. 1994. Association and path analysis in ragi [Eleusine coracana (L.) Gaertn.]. Ann. Agril. Res., 15(4): 428-431.

Ravindran, G. R., Rajagopalan, R., Krishna Moorthy, U. S. and Vijayan, K. P. 1996. Correlation and path coefficient analysis in ragi [Eleusine coracana (L.) Gaertn.] Crop. Res., 12: 359-363.

Singh R. K. and B. D. Choudhary. 1977. Variance and covariance analysis. "Biometrical methods in quantitative genetic analysis.” Kalyani publication, New Delhi, pp.39-68.

Sivasubramanian, V. and Madhavamenon P. 1973. Path analysis for yield and yield components of rice. Madras Agric. J., 60: 1217-1221.

Shanthakumar, G. and Gouda, B. T. S. 1997. Character association and path analysis of grain yield and its components in a segregating population of finger millet [Eleusine coracana (L.) Gaertn.]. Karnataka
Agril. Sci., 10(3): 708-712

Shinde, S. R., Desai, S. V., and Pawar, R. M. 2014. Genetic variability and character association in finger millet [Eleusine coracana (L.) Gaertn.]. Int. plant sci., 9(1): 13-16.

Thakur, S. R., Saini, J. P. 1995. Variation, association and path analysis in finger millet [Eleusine coracana (L.) Gaertn.] under aerial moisture-stress condition. Indian J. Agric. Sci., 65(1): 54-57.

Wilk, S. S. 1932. Certain generalization in the analysis of variance Biometerics., 24: 471-494

Wolie, A. and Dessalegn, T. 2011. Correlation and Path Coefficient Analysis of some yield related traits in Finger Millet [Eleusine coracana (L.) Gaertn.] germplasms in Northwest Ethiopia. African J. Agric. Res., 6(22): 5099-5105.

Wright, S. 1921. Correlation and causation. $J$. Agric. Res. 20: 557-587.

\section{How to cite this article:}

Sneha R. Sapkal, V.V. Bhavsar, K.K. Barhate and Sarika N. Kohakade. 2019. Correlation and Path Analysis for Different Characteristics in Germplasm of Finger Millet (Eleusine coracana (L.) Gaertn.). Int.J.Curr.Microbiol.App.Sci. 8(01): 1020-1027. doi: https://doi.org/10.20546/ijcmas.2019.801.111 